Department of Physics,

Faculty of Science, Al-Azhar University, Assiut 71524, Egypt

\title{
MICROBIOLOGICAL STUDIES ON GERMICIDAL EFFECT OF OZONE GAS ON SOME PATHOGENIC BACTERIA \\ (With 4 Figures)
}

By

E.F. KOTP and M.M. AFIFI*

* Department of Microbiology, Faculty of Science, Al-Azhar University, Assiut 71524, Egypt

(Received at 17/11/2008)
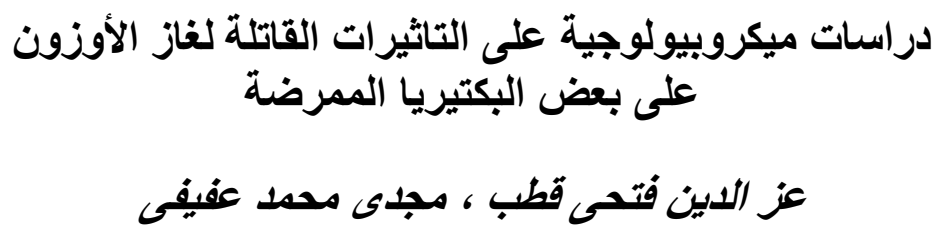

بسبب البكتيريا الممرضة الممثلة كملوثات في الغذاء و المقاومة للعمليات الغذائية والتي

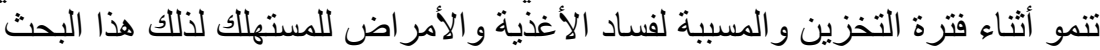

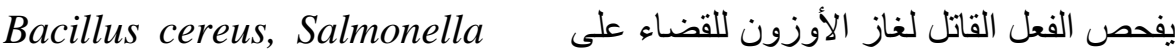
typhi, Klebsiella pneumoniae and Serratia marsecence

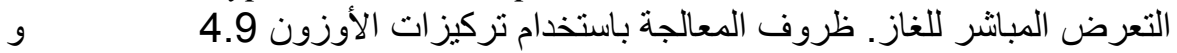

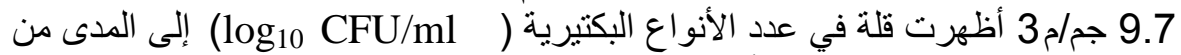

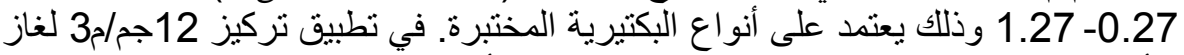

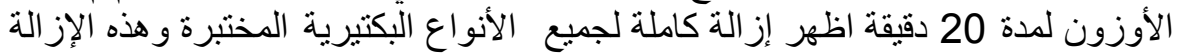

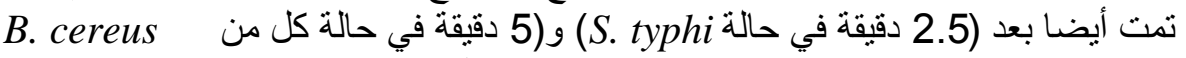

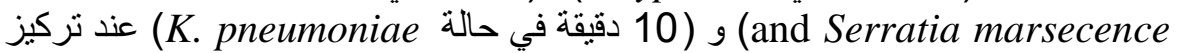

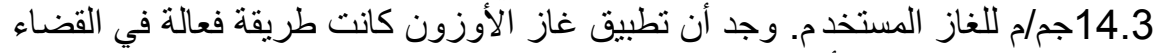
على البكتيريا المسبية للأمر اض في مجال الصحة العامة.

\section{SUMMARY}

Due to pathogenic bacteria, present as contaminants in food, may survive processing, grow during storage, and cause spoilage of food or diseases to consumers. Hence, this research investigates the bactericidal action of gaseous ozone for the elimination of Bacillus cereus, Salmonella typhi, Klebsiella pneumoniae and Serratia marsecence by 
surface exposure technique. Under identical treatment conditions, 4.9 and $9.7 \mathrm{~g} / \mathrm{m}^{3}$ ozone concentrations decreased bacterial counts by 0.27 to $1.27 \log _{10} \mathrm{cfu} / \mathrm{ml}$ depending upon the bacterial species tested. Ozone concentration of $12 \mathrm{~g} / \mathrm{m}^{3}$ up to $20 \mathrm{~min}$, a complete $\log$ reduction took place in the population of all bacteria species tested. Moreover, at 14.3 $\mathrm{g} / \mathrm{m}^{3}$ ozone concentration, a complete log reduction in the number took place at the end of, $2.5 \mathrm{~min}$ of S. typhi, $5 \mathrm{~min}$ of B. cereus and Serratia marsecence, and $10 \mathrm{~min}$ of $\mathrm{K}$. pneumoniae. Ozonation was found to be an effective method to eliminate some of pathogenic microorganisms of great public health concern.

Key words: Ozone application, elimination, pathogenic bacteria.

\section{INTRODUCTION}

Gaseous ozone treatment has bactericidal effect on Salmonella enteritidis, inoculated on the surface of the tomatoes and can be used for surface sanitation of $S$. enteritidis on tomatoes before storage at different conditions (Elif et al. 2006). Bacillus cereus survives adverse environmental conditions, adapts and eventually multiplies in foods (Meer et al. 1991). Some strains of B. cereus grew to $\sim 10^{6} \mathrm{cfu} / \mathrm{g}$ and produced toxin in refrigerated foods (Dufrenne et al. 1995).

Jankowski and Doroszkiewicz (1990), studied on analysis of the bactericidal influence of an ozonized blood serum on gram-negative bacilli. They mentioned that, a considerable differences were observed concerning the effect of ozonized normal human serum on Klebsiella, Pseudomonas and Salmonella strains. Inactivation of Klebsiella terrigena (6-log), E. coli (6-log), MS2 (6-log) and poliovirus 1 (>3-log) was observed after $1 \mathrm{~min}$ of ozonation in a $1 \mathrm{~L}$ batch reactor (Tanner et al. 2004).

Ozone has been approved as an antimicrobial agent in foods in the US (FDA 2001). The use of ozone gas has been suggested as an alternative to reduce microbial populations on melon before cutting (Suslow 2004a,b; Selma et al. 2008). Salmonella and other foodborne pathogens attached to the external surfaces of cantaloupes are of great public health concern because they can be transferred to the edible flesh during cutting (Suslow et al. 2000; Ukuku and Sapers, 2001).

Akbas and Ozdemir (2006) studied the effect of different ozone treatments for decontamination of pistachios contaminated with B. cereus and E. coli. They found that, at $1.0 \mathrm{ppm}$ ozone concentration 
for $360 \mathrm{~min}$ of ozonation, B. cereus counts in pistachio kernels and shelled pistachios were reduced $3 \log$ numbers, while $E$. coli counts were decreased by $3.5 \mathrm{log}$ numbers. Moreover, the spoilage microorganisms of vegetables such as onions, potatoes, and sugar beets are also reduced after storage in an atmosphere containing low ozone concentrations (Kim et al. 1999a,b; Gil and Selma 2006).

Therefore, the aims of this study were to determine the effect of ozone concentrations and exposure times for reducing/eliminating $B$. cereus, S. typhi, K. pneumoniae and S. marsecence to be applied in food and medical microbiology fields.

\section{MATERIALS and METHODS}

\section{Ozone}

Dielectric barrier discharge (DBD) laboratory scale cell, designed and prepared as described previously was used. The equipment consists on a gas-tight glass chamber (at temperature of $22 \pm 0.5$, Relative humidity $(\mathrm{RH})$ of $82-86 \%$ ). The equipment provides the supply of $\mathrm{O}_{2}$ gas to feed the ozone generator from a compressed gas cylinder. Gaseous ozone concentration in the chamber was measured with an ozone gas analyzer (HI-AFX-Instrument, USA), as indicated in a previous study (Afifi and Kotp 2004).

Ozonation of inoculated plates continued until the targeted ozone concentration was attained. Gaseous ozone concentrations were chosen based on preliminary experiments on the sensitivity of B. cereus, $S$. typhi, $K$. pneumoniae and $S$. marsecence, to varying concentrations of ozone ( 4.9 to $14.3 \mathrm{~g} / \mathrm{m}^{3}$ ). Excess ozone was neutralized by diverting the gas stream into a reservoir containing $2 \%$ potassium iodide solution. Protective masks and ozone-resistant gloves were worn during the experiments.

\section{Bacterial cultures}

Four bacterial strains were tested in this study. These strains were; Bacillus cereus, IFR/NL94/25, obtained from the milk laboratory, school of Agriculture at Alex university; Salmonella typhi, MSA, obtained from the department of Microbiology, school of Medcine at Assuit University; and both Klebsiella pneumoniae, MCIB-9111, and Serratia marsecence, IMRU-70, were obtained from fermentation biotechnology center at AL-Azhar University. Stock cultures of these bacteria were grown in nutrient broth at $37^{\circ} \mathrm{C}$ for $24 \mathrm{~h}$.

\section{Microbiological inoculation}


Prior to ozonation treatments, bacterial cells were prepared and obtained by scraping overnight cultures from nutrient agar plates, diluted with sterile peptone water solution $(0.1 \%, \mathrm{w} / \mathrm{v})$, and inoculated at a level of $10^{6}$ microorganism $\mathrm{ml}^{-1}$ by the surface spread plating technique.

Inoculated plates were divided into six separate Petri plates (half for control and half for treatment). The plates were, placed into the ozonation chamber after the desired ozone concentrations were attained, and were incubated for $48 \mathrm{~h}$ at $37{ }^{\circ} \mathrm{C}$. Colonies were counted by colony forming units technique. Results obtained for counting were expressed as $\log \mathrm{cfu} \mathrm{ml}^{-1}$.

\section{Statistical analysis}

Initially, microbial population of control (untreated plates) averaged 2.39, 2.35, 2.40, and $2.41 \mathrm{log} \mathrm{cfu} / \mathrm{ml}$ for B. cereus (Fig. 1), $S$. typhi (Fig. 2), K. pneumoniae (Fig. 3), and S. marsecence (Fig. 4), respectively. Each ozonation trial was performed with three replicates. The data obtained for each treatment evaluated were submitted to analysis of variance ( $\mathrm{F}$ test) to analyze data. The mean value was compared at 5\% level of significantly using the last significance differences (LSD) test (Gomez and Gomez 1998).

\section{RESULTS}

The efficacy of $9.7 \mathrm{~g} / \mathrm{m}^{3} / 20 \mathrm{~min}$ ozone treatment on microbial inactivation was somewhat improved as compared to $4.9 \mathrm{~g} / \mathrm{m}^{3} / 20 \mathrm{~min}$ ozone treatment on both $S$. typhi (Fig. 2) and K. pneumoniae (Fig. 3), being especially more effective on both $B$. cereus (Fig. 1) and $S$. marsecence (Fig. 4). Thus, $9.7 \mathrm{~g} / \mathrm{m}^{3} / 20 \mathrm{~min}$ ozone treatment produced high significant reduction in, S. typhi counts by $0.27 \mathrm{log} \mathrm{cfu} / \mathrm{ml}, K$. pneumoniae counts by 0.73, B. cereus counts by $1.27 \mathrm{log} \mathrm{cfu} / \mathrm{ml}$ and $S$. marsecence counts by $1.26 \log \mathrm{cfu} / \mathrm{ml}$. 


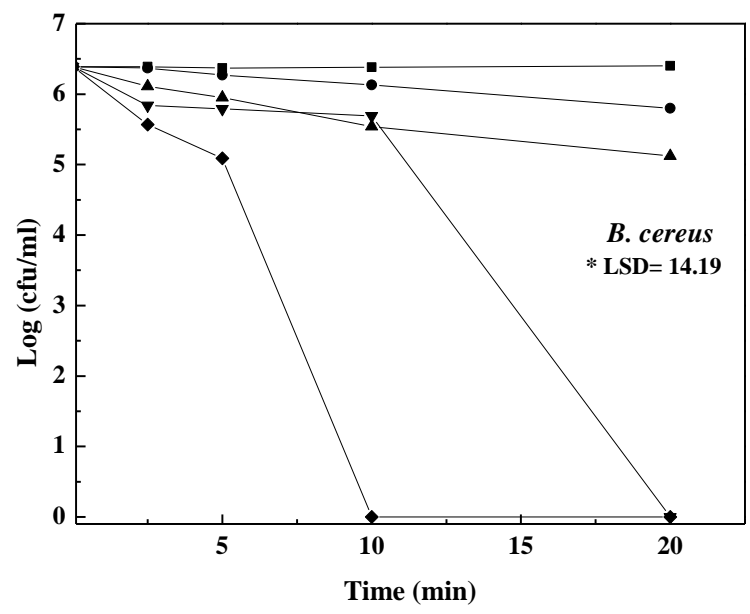

Fig. 1: Comparative effects of ozone concentrations (•) $4.9 \mathrm{~g} / \mathrm{m}^{3}$, (ム) $9.7 \mathrm{~g} / \mathrm{m}^{3},(\nabla) 12 \mathrm{~g} / \mathrm{m}^{3}$ and $(\bullet) 14.3 \mathrm{~g} / \mathrm{m}^{3}$ on population of $B$. cereus (.) control. Values are means of three experiments with triplicate determinations per experiment. Asterisks represent LSD at $\mathrm{P} \leqslant 0.0001$. (Kotp, E. F. and Afifi, M. M.).

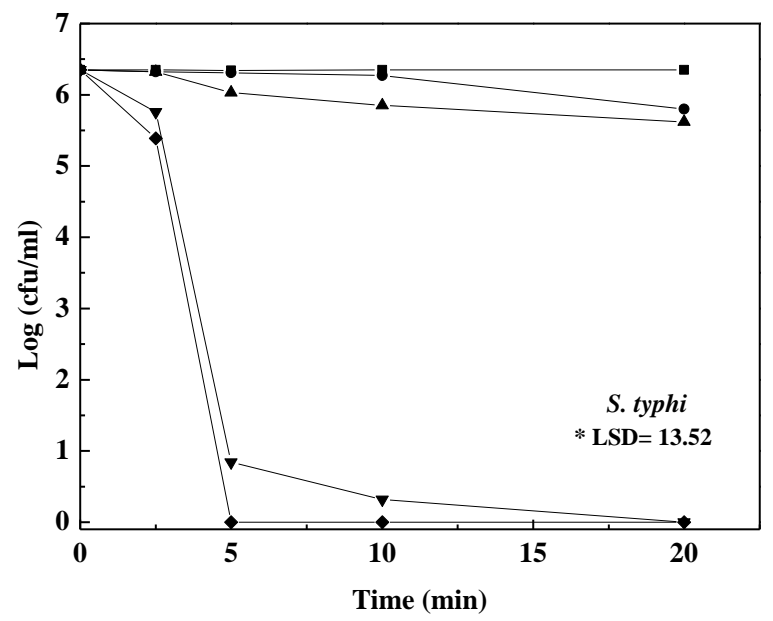

Fig. 2: Comparative effects of ozone concentrations (•) $4.9 \mathrm{~g} / \mathrm{m}^{3}$, (४) $9.7 \mathrm{~g} / \mathrm{m}^{3},(\boldsymbol{v}) 12 \mathrm{~g} / \mathrm{m}^{3}$ and $(\bullet) 14.3 \mathrm{~g} / \mathrm{m}^{3}$ on population of $S$. typhi (.) control. Values are means of three experiments with triplicate determinations per experiment. Asterisks represent LSD at $\mathrm{P} \leqslant 0.0001$. (Kotp, E. F. and Afifi, M. M.). 


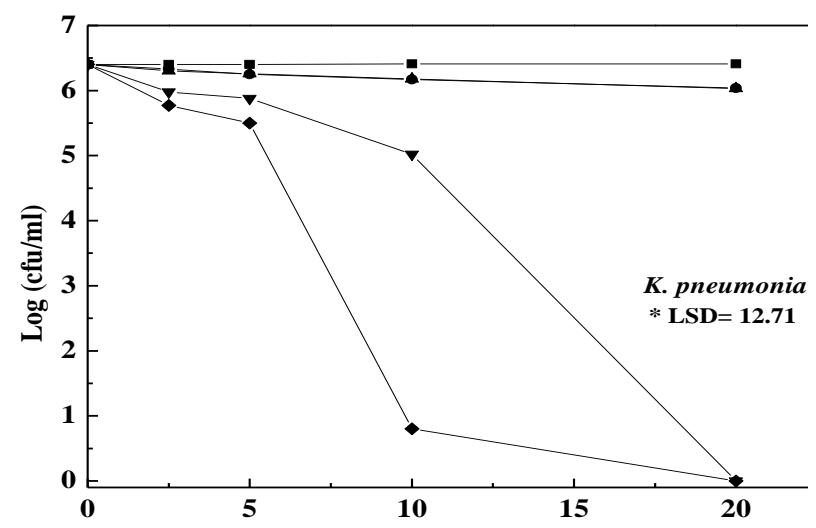

Fig. 3: Comparative effects of ozone concentrations (•) $4.9 \mathrm{~g} / \mathrm{m}^{3}$, (ム) $9.7 \mathrm{~g} / \mathrm{m}^{3},(\nabla) 12 \mathrm{~g} / \mathrm{m}^{3}$ and $(\bullet) 14.3 \mathrm{~g} / \mathrm{m}^{3}$ on population of $K$. Pneumoniae(-) control. Values are means of three experiments with triplicate determinations per experiment. Asterisks represent LSD at $\mathrm{P} \leqslant 0.0001$. (Kotp, E. F. and Afifi, M. M.).

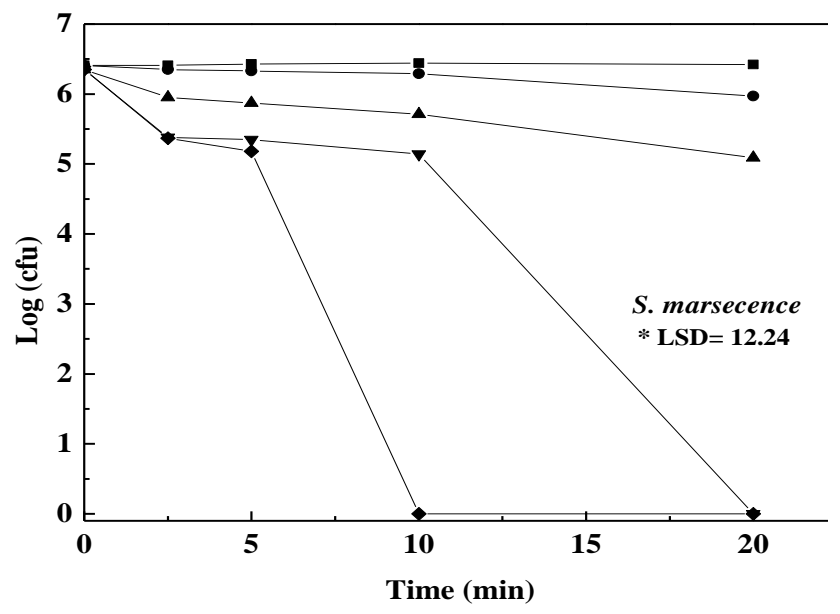

Fig. 4: Comparative effects of ozone concentrations (•) $4.9 \mathrm{~g} / \mathrm{m}^{3}$, (ム) $9.7 \mathrm{~g} / \mathrm{m}^{3},(\nabla) 12 \mathrm{~g} / \mathrm{m}^{3}$ and $(\bullet) 14.3 \mathrm{~g} / \mathrm{m}^{3}$ on population of $S$. marsecence (-) control. Values are means of three experiments with triplicate determinations per experiment. Asterisks represent LSD at $\mathrm{P} \leqslant 0.0001$. (Kotp, E. F. and Afifi, M. M.). 


\section{DISCUSSION}

Results of ozone treatment on microbial activation were consistent with the findings reported by Akbas and Ozdemir (2006). They found that, at $1.0 \mathrm{ppm}$ ozone concentration for $360 \mathrm{~min}$ of ozonation, B. cereus counts in pistachio kernels and shelled pistachios were reduced $3 \log$ numbers.

Selma et al. (2008) demonstrated that, Gaseous ozone $(10,000 \mathrm{ppm}$ for $30 \mathrm{~min}$ under vacuum) reduced viable, recoverable Salmonella from inoculated physiologically mature non-ripe and ripe melons with a maximum reduction of 4.2 and $2.8 \log$ CFU/rind-disk $\left(12.6 \mathrm{~cm}^{2}\right)$, respectively. Moreover, Rowan et al (2007) revealed that, a pulsed-plasma gas-discharge (PPGD) treatments at 4 degrees $\mathrm{C}$ produced significant reductions ( $>$ or $=3 \log \mathrm{CFU} / \mathrm{ml}$ ) in recalcitrant $B$. cereus NCTC 11145 endospore numbers within $30 \mathrm{~s}$.

Similarly, Escherichia coli and B. cereus counts were decreased by $3.5 \mathrm{log}$ numbers at $1.0 \mathrm{ppm}$ ozone concentration for $360 \mathrm{~min}$ ozone treatment in dried figs (Akbas and Ozdemir 2008). Bacillus cereus reduction may be beneficial to quality retention due to this microorganism's contribution to spoilage of perishable, refrigerated product.

At ozone concentration of $14.3 \mathrm{~g} / \mathrm{m}^{3}$ was most effective in slowing down microbial growth at the end of, $2.5 \mathrm{~min}$ of $S$. typhi, $5 \mathrm{~min}$ of both $B$. cereus and $S$. marsecence, and $10 \mathrm{~min}$ of $K$. pneumoniae being high significant reduction $(0.96,1.30,0.23$ and 5.60) $\log \mathrm{cfu} / \mathrm{ml}$, respectively. After these treatments, and at $12 \mathrm{~g} / \mathrm{m}^{3}$ for $20 \mathrm{~min}$, the population of all bacterial species tested completely eliminated too.

Similarly, Heindel et al. (1993), studied the microbicidal effect of ozone in air was tested at concentrations between 50 and 600 micrograms/m3 against the species: Staphylococcus epidermidis, Micrococcus luteus, Arthrobacter citreus, Bacillus subtilis (veg.), E. coli, S. typhimurium, S. marcescens, Pseudomonas fluorescens and Candida albicans. They found that, concentrations of 50 to 100 micrograms $(0) 3 / \mathrm{m}^{3}$ for $1 \mathrm{~h}$ resulted only in little reduction, whereas 500 to 600 micrograms $/ \mathrm{m}^{3}$ for one hour led to $99 \%$ reduction in all bacterial species tested. Ozone was tested against Pseudomonas fluorescens, Escherichia coli O157:H7, Leuconostoc mesenteroides, and Listeria monocytogenes. When kinetic data from a batch reactor were fitted to a dose-response model, a 2-phased linear relationship was observed. A continuous ozone reactor was developed to ensure a 
uniform exposure of bacterial cells to ozone and a constant concentration of ozone during the treatment (Kim and Yousef 2000).

In contrast, Gehring et al. 1990, studied the germicidal influence of various antiseptics on the bacterial and fungal flora of leg ulcers in vitro. They demonstrated that, the treatment with ozone resulted in sufficient inactivation of germs with the only exceptions of Serratia and Klebsiella species. Moreover, Smilanick (2003), demonstrated that, doses of ozone required to rapidly kill post harvest microorganisms in a few minutes, or even hours of exposure, are very high. Therefore, it is important to recognize that technique aimed at eliminating the pathogenic microorganisms of great public health significance.

\section{REFERENCES}

Afifi, M.M. and Kotp, E.F. (2004): Surface germicidal effects of ozone on Staphylococcus aureus, Candida albicans and some fungi. The sec. Int. Conf. for Develop. Env. in The Arab World, Assiut, Egypt. pp. 3-12.

Akbas, M.Y. and Ozdemir, M. (2006): Effectiveness of ozone for inactivation of E. coli and B. cereus in pistachios. Int. J. Food Sci. Technol. 41, 513-519.

Akbas, M.Y. and Ozdemir, M. (2008): Application of gaseous ozone to control populations of Escherichia coli, Bacillus cereus and Bacillus cereus spores in dried figs. Food Microbiology. 25, 386-391.

Dufrenne, J.; Bijwaard, M.; Giffel, M.; Beumer, R. and Notermans, S. (1995): Characteristics of some psychrotrophic Bacillus cereus isolates. Int. J. Food Microbiol. 27: 175-183

Elif, D.G.; Candan, G. and Alev, B. (2006): Effect of controlled atmosphere storage, modified atmosphere packaging and gaseous ozone treatment on the survival of Salmonella enteritidis on cherry tomatoes. Food Microbiology. 23(5), 430438

FDA, (2001): United States Food and Drug Administration. Secondary direct food additives permitted in food for human consumption, final rule. Federal Register 66, pp. 33829-33830.

Gehring, W.; Glutsch, J.; Schönian, U.; Gehse, M. and Gloor, M. (1990): Comparative study of the effect of various antiseptics and ozone gas on pathogens of ulcus cruris. Z Hautkr. 65(8), 746-750. 
Gil, M.I. and Selma, M.V. (2006): Overview of hazards in fresh-cut produce production. Control and management of food safety hazards. In: J. Jennylynd, Editor, Microbial Hazard Identification in Fresh Fruit and Vegetables, WileyInterscience, Wiley, Germany. 155-220.

Gomez, K.A. and Gomez, A.A. (1984): Statistical procedures for agricultural research. Gohn Wiley \& Sons. Inc. NewYork, USA.

Heindel, T.H.; Streib, R. and Botzenhart, K. (1993): Effect of ozone on airborne microorganisms. Zentralbl Hyg Umweltmed. 194 (56), 464-80.

Jankowski, S. and Doroszkiewicz, W. (1990): Preliminary studies of the effect of ozone on the bactericidal properties of complement. Complement Inflamm. 7(2), 57-62.

Kim, A.E.; Yousef, A.E. and Chism, G.W. (1999a): Use of ozone to inactivate microorganisms on lettuce. J. Food Saf. 19, 17-34.

Kim, J.G.; Yousef, A.E. and Dave, S.A. (1999b): Application of ozone for enhancing the microbiological safety and quality of foods: a review. J. Food Prot. 62, 1071-1087.

Kim, J.G. and Yousef, A.E. (2000): Inactivation kinetics of foodborne spoilage and pathogenic bacteria by ozone. J. Food Sci. 65, 521-528.

Meer, R.R.; Baker, J.; Bodyfelt, F.W. and Griffiths, M.W. (1991): Psychrotrophic Bacillus species in fluid milk products: a review. J. Food Prot. 54, 969-979.

Rowan, N.J.; Espie, S.; Harrower, J.; Anderson, J.G.; Marsili and MacGregor, S.J. (2007): Pulsed-plasma gas-discharge inactivation of microbial pathogens in chilled poultry wash water. J. Food Prot. 70, 12, 2805-22810.

Selma, M.V.; Ibáñez, A.M.; Cantwell, M. and Suslow, T.V. (2008): Effect of gaseous ozone and hot water on microbial and sensory quality of cantaloupe and potential transference of E. coli O157: H7 during cutting, Food Microbiol. 25, 162-168.

Smilanick, J.L. (2003): Use of ozone in storage and packing facilities. In: Washington Tree Fruit Postharvest Conference, Wenatchee, WA. WSU-TFREC Postharvest Information Network. 
Suslow, T.V. (2004a): Minimizing the risk of foodborne illness associated with cantaloupe production and handling in California. California Cantaloupe Advisory Board, University of California, Davis. Agricultural and Natural Resources Publication, California, CA.

Suslow, T.V. (2004b): UC ANR Publication 8133. Ozone Applications For Edible Horticultural Commodities.

Suslow, T.V.; Zuñega, M.; Wu, J.; Harris, L.J. and Parnell, T. (2000): Potential for transference of inoculated and indigenous bacteria from the non-wounded rind of melons to the interior edible flesh. In: Annual Meeting, International Association of Food Protection, Atlanta, GA. (Abstract P71).

Tanner, B.D.; Kuwahara, S.; Gerba, C.P. and Reynolds, K.A. (2004): Evaluation of electrochemically generated ozone for the disinfection of water and wastewater. Water Sci Technol. 50(1), 19-25.

Ukuku, D.O. and Sapers, G.M. (2001): Effect of sanitizer treatments on Salmonella stanley attached to the surface of cantaloupe and cell transfer to fresh-cut tissues during cutting practices. J. Food Prot. 64, 1286-1291. 